\begin{tabular}{|c|c|c|}
\hline \multicolumn{3}{|c|}{ TOTOBUANG } \\
\hline Volume 6 & Nomor 2, Desember 2018 & Halaman $331-347$ \\
\hline
\end{tabular}

\title{
PENINGKATAN KEMAMPUAN MENGIDENTIFIKASI UNSUR-UNSUR INTRINSIK CERITA PENDEK MELALUI MODEL RESPONS ANALISIS SISWA KELAS XI IPA2 SMA NEGERI 1 CENDANA KABUPATEN ENREKANG (Increasing Ability to Identify Intrinsic Elements of Short Stories Through the "Response Analysis "Model of Class XI Students 2 of Cendana 1 Public High School in Enrekang Regency)
}

\author{
Syaidah \\ Universitas Iqra Buru \\ Jalan Prof. Dr. Abdurrahman Basalamah, M. Si., Namlea, Maluku \\ Pos-el: Gsyaidahonion@yahoo.com
}

(Diterima: 26 November 2018; Direvisi: 6 Desember 2018; Disetujui: 21 Desember 2018)

\begin{abstract}
This study aims to describe the improvement of the learning process and learning outcomes identify the intrinsic elements of short stories through the "response analysis" model of class XI IPA 2 Cendana 1 Public High School, Enrekang Regency. This research was conducted in two cycles, each cycle took place 2 meetings and each cycle consisted of 4 stages, namely: planning, action, observation, and reflection. This research is a classroom action research with exposure to qualitative descriptive data and quantitative data. Qualitative data is obtained from the observation sheet of each implementation of the action (learning process), and quantitative data is obtained from the final test of each cycle. The subjects in this study were students of class XI IPA 2, amounting to 20 people. The action given is intended to find out in the form of improving the learning process and learning outcomes in the first cycle. The second cycle is in the form of corrective actions towards deficiencies experienced in the first cycle. The results of data analysis conducted on the results of the research in the first cycle and the second cycle concluded that, learning identifies intrinsic elements in students of class XI IPA 2 Cendana State High School 1 Enrekang District through the "response analysis" model can improve the learning process and learning outcomes identifying intrinsic elements of short stories.

Keywords: short stories, intrinsic elements, response analysis model
\end{abstract}

\begin{abstract}
Abstrak
Penelitian ini bertujuan untuk mendeskripsikan peningkatan proses pembelajaran dan hasil pembelajaran mengidentifikasi unsur-unsur intrinsik cerita pendek melalui model respons analisis siswa kelas XI IPA 2 SMA Negeri 1 Cendana Kabupaten Enrekang. Penelitian ini dilaksanakan dalam dua siklus, setiap siklus berlangsung dua kali pertemuan dan setiap siklus terdiri atas empat tahap yaitu: tahap perencanaan, pelaksanaan tindakan, observasi, dan refleksi. Penelitian ini merupakan penelitian tindakan kelas dengan pemaparan data deskriptif kualitatif dan data kuantitatif. Data kualitatif diperoleh dari lembar observasi dari setiap pelaksanaan tindakan (proses pembelajaran), dan data kuantitatif diperoleh dari tes akhir setiap siklus. Subjek dalam penelitian ini adalah siswa kelas XI IPA 2 yang berjumlah dua puluh orang. Tindakan yang diberikan dimaksudkan untuk mengetahui berupa peningkatan proses pembelajaran dan hasil pembelajaran pada siklus pertama. Adapun siklus kedua berupa tindakan perbaikan terhadap kekurangan-kekurangan yang dialami pada siklus pertama. Hasil analisis data yang dilakukan terhadap hasil penelitian pada siklus pertama dan siklus kedua disimpulkan bahwa, pembelajaran mengidentifikasi unsur-unsur intrinsik pada siswa kelas XI IPA 2 SMA Negeri 1 Cendana Kabupaten Enrekang melalui model respons analisis dapat meningkatkan kemampuan pada proses pembelajaran dan hasil pembelajaran mengidentifikasi unsur-unsur intrinsik cerita pendek.
\end{abstract}

Kata-kata kunci: cerita pendek, unsur intrinsik, model respons analisis

\section{PENDAHULUAN}

Pembelajaran sastra di sekolah tidak berdiri sendiri sebagai sebuah mata pelajaran yang mandiri tetapi hanya menjadi bagian mata pelajaran bahasa Indonesia. Pada hakikatnya, belajar sastra dimaksudkan 
untuk meningkatkan kemampuan siswa mengapresiasi karya sastra. Pembelajaran sastra (puisi, prosa, dan drama) tidak hanya ditunjukkan untuk memberikan pengetahuan tentang sastra tetapi juga untuk menimbulkan daya apresiasi dan daya cipta. Salah satu daya apresiasi dalam pembelajaran sastra adalah keterampilan menyimak.

Melalui pembelajaran sastra Indonesia di sekolah menengah atas, guru mengharapkan agar siswa memiliki wawasan yang memadai tentang sastra, bersikap positif terhadap sastra dan mampu mengembangkan wawasan serta memperoleh pengalaman sastra. Harapan tersebut tidaklah terlampau berlebihan, sebab sekolah menengah atas adalah lembaga pendidikan sebagai lanjutan sekolah umum tingkat pertama.

Karya sastra terdiri atas puisi, prosa fiksi, dan drama. Salah satu bentuk prosa fiksi adalah cerita pendek. Dalam Kurikulum Tingkat Satuan Pendidikan (KTSP) cerita pendek merupakan salah satu materi pembelajaran sastra yang diajarkan di SMA. Kegiatan mengapresiasi cerita pendek adalah salah satu aspek kemampuan dalam pembelajaran sastra yang harus dikuasai siswa yang tercantum dalam standar kompetensi dan kompetensi dasar kelas XI semester II. Salah satu standar kompetensi tersebut adalah memahami pembacaan cerita pendek, kompetensi dasar yang harus dikuasai siswa, yaitu mengidentifikasi tema, alur (plot), tokoh dan penokohan serta latar.

Peneliti mengamati proses

pembelajaran yang berlangsung dan melakukan wawancara terhadap guru bidang studi. Adapun hasil kegiatan survei yang peneliti lakukan adalah 1) siswa kesulitan dalam mengikuti pembelajaran apresiasi sastra; 2) pada saat pembelajaran berlangsung, banyak siswa tidak memperhatikan penjelasan guru, ada yang melamun dan berbicara dengan temannya; 3) siswa kurang aktif dalam pembelajaran apresiasi cerita pendek, sehingga tidak ada interaksi antara guru dan siswa, guru masih kurang menunjukkan sikap komunikatif aktif dengan siswa; 4) guru kesulitan dalam membangkitkan minat belajar apresiasi sastra khususnya cerita pendek. Hal ini disebabkan dalam pembelajaran cerita pendek khususnya dalam mengidentifikasi unsur-unsur intrinsik, guru masih terlihat bersifat monoton yang tidak membangkitkan kreativitas siswa.

Sumbangan pemikiran peneliti untuk menyikapi permasalahan pembelajaran sastra yang terjadi di SMA Negeri 1 Cendana Kabupaten Enrekang diperlukan suatu model pembelajaran yang efektif untuk membangkitkan minat belajar siswa, khususnya dalam mengidentifikasi unsurunsur intrinsik cerita pendek. Model pembelajaran tersebut sudah sesuai dengan kebutuhan siswa, yakni model respons analisis yang secara khusus disediakan untuk pembelajaran sastra.

Berdasarkan uraian tersebut, peneliti tertarik untuk melakukan penelitian tindakan kelas dengan judul penelitian "Peningkatan Kemampuan Mengidentifikasi Unsur-Unsur Intrinsik Cerita Pendek Melalui Model "Respons Analisis" Siswa Kelas XI SMAN 1 Cendana Kabupaten Enrekang" penelitian yang relevan pernah dilakukan oleh Syaifullah pada tahun 2004 akan tetapi belum fokus pada peningkatan kemampuan mengidentifikasi unsur-unsur intrinsik cerita pendek. Adapun judul penelitian tersebut adalah "Penerapan Model Respons Analisis dan Model Moody dalam Pembelajaran Apresiasi Cerita Pendek (Kajian Eksperimen terhadap Siswa Kelas II SMAN Cililin Kabupaten Bandung). Walaupun penelitian ini memperlihatkan hasil yang cukup baik, akan tetapi tingkat keterujiannya belum menyeluruh. Oleh karena itu, penelitian lanjutan yang berkenaan dengan penerapan model respons analisis ini perlu dilakukan lagi agar kesahihan model ini dapat lebih dipertanggungjawabkan. Selain itu, kajian ini akan menjawab apakah penggunaan model respons analisis dapat meningkatkan 
proses mengidentifikasi unsur-unsur intrinsik cerita pendek siswa kelas XI IPA 2 SMA Negeri 1 Cendana Kabupaten Enrekang? dan apakah penggunaan model respons analisis dapat meningkatkan hasil mengidentifikasi unsur-unsur intrinsik cerita pendek siswa kelas XI IPA 2 SMA Negeri 1 Cendana Kabupaten Enrekang?

$$
\text { Kajian bertujuan untuk }
$$

mendeskripsikan keefektifan pembelajaran model respons analisis dalam meningkatkan proses mengidentifikasi unsur-unsur intrinsik cerita pendek siswa kelas XI IPA 2 SMA Negeri 1 Cendana Kabupaten Enrekang. selain itu, kajian ini mendeskripsikan keefektifan pembelajaran model respons analisis dalam meningkatkan hasil mengidentifikasi unsur-unsur intrinsik cerita pendek siswa kelas XI IPA 2 SMA Negeri 1 Cendana Kabupaten Enrekang.

Manfaat teoretis diharapkan dari kajian ini agar dapat dijadikan acuan atau pedoman bagi lembaga atau guru untuk menggunakan model respons analisis dalam pembelajaran mengidentifikasi unsur-unsur intrinsik cerita pendek. Manfaat praktis berikutnya adalah bagi siswa yaitu diharapkan dapat membantu siswa yang mengalami kesulitan dalam mengidentifikasi unsur-unsur intrinsik cerita pendek. Selanjutnya, bagi akademisi/lembaga pendidikan, dan guru diharapkan menjadi bahan Bagi peneliti, diharapkan menjadi masukan dalam meneliti dan mengembangkan penelitian lebih lanjut berkenaan dengan model respons analisis unsur-unsur intrinsik cerita pendek pada pelajaran Bahasa dan Sastra Indonesia.

\section{LANDASAN TEORI}

\section{Kemampuan Menyimak}

Kajian menyimak dibagi dalam tiga hal pokok yaitu a) pengertian menyimak; b) proses menyimak; c) mana bagian ini?

\section{a. Pengertian Menyimak}

Menurut Tarigan (2008:28), menyimak adalah suatu proses kegiatan mendengarkan lambang-lambang lisan dengan dengan penuh perhatian, pemahaman, apresiasi, serta interpretasi untuk memperoleh informasi, menangkap isi atau pesan serta memahami makna komunikasi yang telah disampaikan oleh sang pembicara melalui ujaran atau bahasa lisan. Selain itu, Anderson menyatakan, menyimak bermakna mendengarkan dengan penuh pemahaman dan perhatian serta apresiasi (Tarigan, 2008:30).

\section{b. Proses Menyimak}

Proses menyimak terbagi dalam beberapa tahap, yaitu:

1) Tahap Mendengar, yakni dalam tahap ini kita baru mendengar segala sesuatu yang dikemukakan oleh pembicara dalam ujaran atas pembicaraannya.

2) Tahap Memahami, yakni setelah kita mendengar maka ada keinginan bagi kita untuk mengerti atau memahami dengan baik isi pembicaraan yang disampaikan oleh pembicara.

3) Tahap Menginterpretasi, yakni penyimak yang baik, yang cermat dan teliti, belum puas kalau hanya mendengar dan memahami ujaran sang pembicara, dia ingin menafsirkan isi, butir-butir pendapat yang terdapat dan terdapat dan tersirat dalam ujaran itu.

4) Tahap Mengevaluasi yakni setelah memahami serta dapat menafsir isi pembicaraan, penyimak pun mulailah menilai pendapat serta gagasan pembicara mengenai keunggulan dan kelemahan serta kebaikan dan kekurangan pembicara.

5) Tahap Menanggapi, yakni penyimak menyambut, mencanamkan, dan menyerap serta menerima gagasan atau ide yang dikemukakan oleh pembicara dalam ujaran atau pembicaraannya.

\section{Karya Sastra}

Kajian mengenai karya sastra dibagi dalam tiga hal pokok yaitu a) pengertian karya sastra; b) pengertian dan karakteristik 
karya sastra; c) unsur-unsur intrinsik cerita pendek.

\section{a. Pengertian Karya Sastra}

Sastra merupakan bagian dari karya seni yang keduanya merupakan unsur integral dari kebudayaan dan usianya sangat tua. Kedua unsur integral hampir bersamaan dengan kehadiran manusia.

Menurut Teeuw (1988:23) sastra berasal dari kata sas dan tra. Sas dalam bahasa Indonesia mempunyai pengertian 'mengajar, mengarahkan, memberi petunjuk', dan tra berarti 'sarana, alat'. Jadi, sastra dapat diartikan alat untuk mengajar, buku petunjuk, buku instruksi atau pengajaran. Selanjutnya Teeuw menambahkan bahwa penambahan awal su pada kata sastra berarti 'baik, indah' sehingga susastra dapat dibandingkan dengan belles letters (bahasa Perancis), yaitu 'sastra yang bernilai estetika' atau belleterie (bahasa Belanda) atau letter kunde (bahasa Belanda) yang bermakna 'sastra indah' terjemahan harfiah dari literature (bahasa Latin) yang berarti 'puisi, sastra'.

\section{b. Pengertian dan Karakteristik Cerita Pendek}

Kajian mengenai pengertian dan karakteristik cerita pendek terdiri dari dua hal pokok yakni: a) pengertian cerita pendek; b) unsur-unsur yang membangun cerita pendek.

Menurut Jassin (dalam Nurgiyantoro, 2007:10), cerita pendek adalah sebuah cerita yang selesai dibaca dalam satu kali duduk, kira-kira berkisar antara setengah sampai dua jam. Cerita pendek menyajikan suatu keadaan tersendiri atau suatu keadaan tersendiri atau suatu kelompok keadaan yang memberi kesan tunggal kepada pembacanya. Cerita pendek menuntut penceritaan yang serba ringkas, tidak sampai pada detail-detail khusus yang kurang penting dan bersifat memperpanjang cerita karena bentuknya pendek.
Pendapat yang dikemukakan oleh Kosasih (2009:391) mengatakan bahwa cerita pendek adalah karangan pendek yang berbentuk prosa. Dalam cerita pendek dikisahkan sepenggal kehidupan tokoh, yang penuh pertikaian, peristiwa yang mengharukan atau menyenangkan, dan mengandung kesan yang tidak mudah dilupakan.

Dari beberapa pendapat sebelumnya, dapat disimpulkan bahwa cerita pendek adalah cerita yang dapat selesai dibaca dalam waktu singkat.

Unsur intrinsik adalah unsur-unsur yang membangun karya sastra itu sendiri. Unsur-unsur inilah yang menyebabkan karya sastra hadir sebagai karya sastra. Sedangkan unsur ekstrinsik adalah unsur luar yang memengaruhi pengarang pada saat penciptaan cerita.

\section{c. Unsur-Unsur Intrinsik Cerita Pendek}

Kajian mengenai unsur-unsur intrinsik cerita pendek dibagi dalam empat hal pokok yakni a) tema; b) plot/alur; c) tokoh dan penokohan; d) latar.

Istilah tema menurut Scharbach (dalam Aminuddin, 2009:31) berasal dari bahasa Latin yang berarti 'tempat meletakkan suatu perangkat'. Disebut demikian karena tema adalah ide yang mendasari suatu cerita sehingga berperanan juga sebagai pangkal tolak pengarang dalam memaparkan karya fiksi yang diciptakannya. Selanjutnya, Brooks (dalam Aminuddin, 2009: 92) mengungkapkan bahwa dalam mengapresiasi tema suatu cerita, apresiator harus memahami ilmu-ilmu humanitas karena tema sebenarnya merupakan pendalaman dan hasil kontemplasi pengarang yang berkaitan dengan masalah kemanusiaan serta masalah lain yang bersifat kemanusiaan.

Menurut Dola (2007:16) tema adalah sesuatu yang menjadi pikiran atau persoalan pengarang yang kalau diikuti dengan cara pemecahan masalah maka akan menghasilkan amanat. Selanjutnya Nasution 
(dalam Dola, 2007:16), berpendapat bahwa tema adalah ide pokok yang dibedakan atas tema mayor dan tema minor.

Dengan adanya tema, pengarang mempunyai pedoman dalam menyusun ceritanya untuk mencapai sasaran yang diinginkan. Tema mempunyai tiga fungsi, yaitu sebagai pedoman bagi pengarang untuk menggarap, sasaran atau tujuan penggarapan cerita, dan mengingat peristiwa-peristiwa yang diceritakan dalam suatu alur. Selanjutnya, menurut Stanton (2007:36) mengartikan tema sebagai "makna sebuah cerita yang secara khusus menerangkan sebagian besar unsurnya dengan cara yang sederhana".

Menurut Stanton (2007:44-46) kriteria-kriteria yang hendak dipenuhi dalam menganalisis tema adalah

1. Interpretasi yang baik hendaknya selalu mempertimbangkan berbagai detail menonjol dalam sebuah cerita;

2. Interpretasi yang baik hendaknya tidak terpengaruh oleh berbagai detail cerita yang saling kontradiksi;

3. Interpretasi yang baik hendaknya tidak sepenuhnya bergantung pada bukti-bukti yang tidak secara jelas diutarakan (hanya disebut secara implisit);

4. Interpretasi yang dihasilkan hendaknya diujarkan secara jelas oleh cerita bersangkutan.

Menurut Aminuddin (2009:83), plot adalah rangkaian cerita yang dibentuk oleh tahapan-tahapan peristiwa sehingga menjalin suatu cerita yang dihadirkan oleh para pelaku dalam suatu cerita.

Menurut Stanton (2007:26), alur merupakan rangkaian peristiwa-peristiwa dalam sebuah peristiwa. Istilah alur biasanya terbatas pada peristiwa-peristiwa yang berhubungan secara kausal yakni peristiwa yang menyebabkan atau menjadi dampak dari peristiwa lain dan tidak dapat diabaikan karena akan berpengaruh pada keseluruhan karya.

Selanjutnya Kenny (dalam Nurgiyantoro, 2007:113) mengemukakan bahwa plot sebagai peristiwa-peristiwa yang ditampilkan dalam cerita yang tidak bersifat sederhana, karena pengarang menyusun peristiwa-peristiwa itu berdasarkan sebab akibat.

Menurut Froster (dalam Nurgiyantoro, 114-116) mengemukakan bahwa plot itu bersifat misterius dan intelektual. Bersifat misterius karena plot menampilkan kejadian-kejadian yang mengandung konflik yang mampu menarik atau bahkan mencekam pembaca sehingga mendorong pembaca untuk mengetahui kejadian-kejadian berikutnya. Karena plot bersifat misterius maka untuk memahaminya diperlukan kemampuan intelektual. Tanpa disertai daya intelektual tidak mungkin orang memahami plot dengan baik.

Tasrif (dalam Nurgiyantoro, 2007:149-150) membedakan tahapan plot menjadi lima bagian, yakni

1) Tahap penyituasian, tahap yang terutama berisi pelukisan dan pengenalan situasi latar dan tokoh cerita. Tahap ini merupakan tahap pembukaan cerita, pemberian informasi awal yang berfungsi melandastumpui cerita yang dikisahkan pada tahap berikutnya.

2) Tahap pemunculan konflik, merupakan tahap awalnya munculnya konflik dan konflik-konflik itu akan berkembang pada tahap berikutnya.

3) Tahap peningkatan konflik, konflik yang telah dimunculkan pada tahap sebelumnya semakin berkembang dan dikembangkan kadar intensitasnya.

4) Tahap klimaks, konflik atau pertentangan-pertentangan yang terjadi yang diakui dan ditimpakan kepada tokoh cerita mencapai titik intensitas puncak. Klimaks sebuah cerita akan dialami oleh tokoh utama yang berperan sebagai pelaku dan penderita terjadinya konflik utama.

(1) Tahap penyelesaian, konflik yang telah mencapai klimaks diberi penyelesaian, ketegangan dikendurkan. 
Aminuddin (2009:79) tokoh adalah pelaku mengemban peristiwa dalam cerita fiksi sehingga peristiwa itu mampu menjalin suatu cerita, sedangkan cara pengarang menampilkan tokoh atau pelaku itu disebut penokohan.

Dalam menentukan siapa tokoh utama dan siapa tokoh tambahan dalam suatu cerita pendek dapat ditentukan melalui

1) Lewat petunjuk yang diberikan oleh pengarangnya, tokoh utamanya merupakan tokoh yang sering diberi komentar dan dibicarakan oleh pengarangnya, sedangkan tokoh tambahan hanya dibicarakan ala kadarnya;

2) Lewat judul cerita, misalnya dalam cerita Sitti Nurbaya dan Maling Kundang;

3) Melihat keseringan pemunculannya dalam suatu cerita

4) Menurut Aminuddin (2009:80-81) dalam upaya memahami watak pelaku, pembaca dapat menulusurinya lewat;

5) Tuturan pengarang terhadap karakteristik pelakunya

6) Gambaran yang diberikan pengarang melalui gambaran lingkungan kehidupannya maupun caranya berpakaian

7) Menunjukkan bagaimana perilakunya

8) Melihat bagaimana tokoh itu berbicara tentang dirinya sendiri

9) Memahami bagaimana cara pikirannya

10) Melihat bagaimana tokoh lain berbicara tentangnya

11) Melihat bagaimana tokoh-tokoh yang lain itu memberikan reaksi terhadapnya

12) Melihat bagaimana tokoh itu mereaksi tokoh yang lainnya.

Menurut Stanton (2007:35) latar adalah lingkungan yang melingkupi sebuah peristiwa dalam cerita, semesta yang berinteraksi dengan peristiwa-peristiwa yang sedang berlangsung. Abrams (dalam Nurgiyantoro, 2007:216) menyatakan bahwa latar adalah landas tumpu, menyaran pada pengertian tempat, hubungan waktu, dan lingkungan sosial tempat terjadinya peristiwa-peristiwa yang diceritakan.

Menurut Nurgiyantoro (2007:227-

237), unsur latar dapat dibedakan atas

1) Latar tempat, menyarankan pada lokasi terjadinya peristiwa yang diceritakan dalam sebuah karya fiksi.

2) Latar waktu, berhubungan dengan masalah kapan terjadinya peristiwaperistiwa yang diceritakan dalam sebuah karya fiksi.

3) Latar sosial, menyarankan pada hal-hal yang berhubungan dengan perilaku sosial masyarakat di suatu tempat yang diceritakan dalam karya fiksi.

\section{Model Respon Analisis}

Kajian model "respons analisis" dapat dibagi dalam tiga model yakni 1) pengertian model respons analisis; 2) konsep dasar model respons analisis; 3) bentuk model respons analisis yang sifatnya bervariasi; 4) prosedur pembelajaran model respons analisis.

\section{1) Pengertian Model Respons Analisis}

Model respons analisis

diperkenalkan oleh beberapa pakar, mereka antara lain Jane P. Tomskins. N. R. Helland, Louise M. Rosenbalt, R.E Probst, dan David Bleich. Menurut Rosenbalt (dalam Hajrah, dkk, 2009:17), model respons analisis memiliki karakter tersendiri. Proses pemahaman pembaca tidak hanya terbatas sampai menganalisis dan memahami maknanya semata, melainkan sampai pada pemberian makna yang direalisasikan melalui pemberian respons terhadap teks sastra yang menjadi bahan bacaannya.

\section{2) Konsep Dasar Model Respons Analisis}

Pembelajaran sastra bukanlah pembelajaran tentang sastra, tetapi pembelajaran yang berupaya melibatkan siswa dengan karya sastra yang dijadikan bahan pembelajaran. Lewat pembelajaran dengan cara tersebut, siswa diharapkan memiliki kemampuan dan keterampilan 
untuk mengapresiasi karya sastra. Dengan demikian, siswa benar-benar pada sebuah suasana nyata yaitu berhadapan langsung dengan fakta sehingga siswa dapat melakukan eksplorasi dan eksploitasi sastra. Menurut Rosenbalt (dalam Hajrah, dkk, 2009:18-19), konsep pembelajaran sastra terdiri dari

a) Konsep persamaan pengalaman.

b) Konsep peran pembaca dan kebebasan memberikan makna.

c) Konsep humanitas pada pribadi anak dan kehidupan sosial.

d) Konsep pelaksanaan interaksi dan transaksional.

Pembelajaran sastra hendaknya dilakukan melalui interaksi yang bersifat transaksional. Cooper (dalam Hajrah, dkk, 2009:19) menyatakan bahwa yang dimaksud dengan transaksional ialah kegiatan interaksi yang mencangkup cara, yaitu

(1) Interaksi karya sastra ke pembaca.

(2) Interaksi dari pembaca ke karya sastra.

(3) Interaksi dari pembaca ke pembaca lainnya.

(4) Interaksi dari karya sastra ke karya sastra lainnya.

e) Konsep peranan guru sastra dalam pengajaran sastra.

\section{3) Bentuk Model Respons Analisis Sifatnya Bervariasi}

Dalam kenyataannya, model respons analisis merupakan sebuah model yang memberi penekanan pada berbagai bentuk diskusi dalam kegiatan pembelajarannya. Melalui kegiatan inilah, siswa menampilkan responsnya.

Menurut Taba (dalam Gani,
1988:8-26) terdapat tingkat-tingkat
$\begin{aligned} & \text { pertanyaan yang dapat mengundang respons } \\ & \text { siswa, yaitu }\end{aligned}$

a) Tingkat I. Pengertian, guru mengajukan pertanyaan untuk memastikan pengertian siswa tentang makna puisi, cerita pendek dan drama. b) Tingkat II. Penafsiran, guru mengajukan pertanyaan jenis ini untuk membantu siswa menelusuri dengan saksama hubungan-hubungan dan konflik-konflik di dalam sebuah cipta sastra.

c) Tingkat III. Penghubungan, guru mendorong siswa untuk menampilkan nilai-nilai dan pengalamanpengalamannya ke dalam cipta sastra itu.

d) Tingkat $I V$. Penjelasan melintasi wacana, guru menggunakan sastra sebagai titik loncat untuk mencari hubungan gagasangagasan yang memungkinkan pengembangan ke arah wilayah baru.

Dari paparan tersebut, jelas bahwa model respons analisis memperlakukan siswa sebagai pemberi makna terhadap karya sastra. Karena itu penjelajahan siswa terhadap karya sastra secara langsung merupakan sebuah keharusan yang tidak bisa ditawar-tawar lagi, manakala guru menggunakan model respons analisis dalam pembelajaran apresiasi sastra.

\section{4) Prosedur Pembelajaran Model Respons Analisis}

Mengacu pada pendapat yang dikemukakan oleh Gani (1988:248-249) prosedur yang digunakan dalam pengajaran dengan menggunakan respons terdiri atas tiga langkah, yaitu

a) Membaca teks sastra. Proses membaca dilakukan sebelum kegiatan belajar mengajar berlangsung.

b) Mengungkapkan respons. Setelah selesai belajar siswa diminta reaksinya dengan cara mengungkapkan apa saja yang terlintas di benaknya.

c) Mendiskusikan respons. Kegiatan diskusi ini dilakukan dengan cara membahas beberapa respons yang telah disampaikan oleh siswa.

\section{METODE PENELITIAN}

Penelitian ini digolongkan ke dalam penelitian tindakan kelas (classroom action research). Mekanisme pelaksanaannya dilakukan dalam dua siklus dan setiap siklus 
berlangsung dalam dua kali pertemuan. Setiap siklus masing-masing dilaksanakan dengan empat tahap, yaitu (1) perencanaan (persiapan); (2) tindakan (aksi); (3) pengamatan (observasi); dan (4) refleksi (evaluasi). Penelitian tindakan kelas ini merupakan salah satu upaya untuk memperbaiki dan meningkatkan kualitas pembelajaran serta membantu memberdayakan guru dalam memecahkan masalah pembelajaran di kelas. Dengan demikian guru dapat mengetahui secara jelas masalah-masalah yang ada di kelas dan solusi pemecahan dalam mengatasi masalah tersebut.

Jenis penelitian yang digunakan dalam penelitian ini adalah Penelitian Tindakan Kelas dengan pemaparan data deskriptif kualitatif dan data kuantitatif. Data kualitatif diperoleh dari lembar observasi dan dokumentasi dalam setiap pelaksanaan tindakan (proses pembelajaran), serta data kuantitatif diperoleh dari tes akhir setiap siklus.

Penelitian ini dilaksanakan pada akhir bulan November sampai awal bulan September dengan alokasi waktu 4 kali pertemuan di kelas XI SMA Negeri 1 Cendana Kabupaten Enrekang. Adapun subjek dalam penelitian adalah siswa XI IPA 2 sebanyak 20 siswa.

Data pada penelitian ini adalah data proses dan data hasil pembelajaran. Data proses pembelajaran meliputi dua hal, yakni:

a) Aktivitas guru dan siswa ketika proses penerapan model respons analisis dalam pembelajaran mengidentifikasi unsurunsur intrinsik cerita pendek siswa kelas XI IPA 2 SMA Negeri 1 Cendana Kabupaten Enrekang.

b) Aktivitas guru dan siswa dalam uji kompetensi mengidentifikasi unsur-unsur intrinsik cerita pendek.

Data hasil pembelajaran dalam penelitian ini berupa kemampuan mengidentifikasi unsur-unsur intrinsik cerita pendek siswa kelas XI IPA 2 SMA Negeri 1 Cendana Kabupaten Enrekang.

Sumber data penelitian ini ada 2 yaitu sumber data lisan dan tertulis. Sumber data lisan adalah informan yang memiliki pengetahuan tentang cara kerja siswa dalam hal ini guru. Sedangkan, sumber data tertulis adalah hasil kerja siswa kelas XI IPA 2 sebanyak 20 siswa.

Penelitian ini dilaksanakan dalam dua siklus, di mana setiap siklus saling berkaitan dalam hal rangkaian kegiatannya. Artinya bahwa pelaksanaan pada siklus pertama akan dilanjutkan pada siklus kedua yang merupakan pelaksanaan perbaikan dari siklus kedua. Siklus pertama dan siklus kedua meliputi (1) perencanaan tindakan, (2) pelaksanaan tindakan, (3) pengamatan, dan (4) refleksi.

Teknik pengumpulan data adalah cara yang dilakukan dalam mengumpulkan data yang berhubungan dengan penelitian ini. Arikunto (2006:150-159) menyebutkan beberapa cara teknik pengumpulan data yaitu (1) tes, (2) kuesioner atau angket, (3) wawancara, (4) observasi, (5) skala bertingkat, dan (6) dokumentasi. Namun, dalam penelitian ini peneliti hanya memilih empat dari beberapa teknik yang disebutkan di atas yaitu (1) teknik dokumentasi, (2) teknik observasi, dan (3) teknik tes.

Data yang terkumpul dianalisis secara deskriptif kualitatif dan deskriptif kuantitatif. Untuk data proses dianalisis secara deskriptif kualitatif, sedangkan data hasil belajar dianalisis secara deskriptif kuantitatif.

Data kualitatif yaitu data yang berupa informasi yang memberi gambaran tentang suasana kelas yang diperoleh melalui lembar observasi. Data kuantitatif adalah data skor hasil tes yang menggambarkan kemampuan mengidentifikasi unsur-unsur intrinsik cerita pendek. Data tersebut direduksi berdasarkan masalah yang diteliti, menyajikan dat, dan 
terakhir penyimpulan atau verifikasi. Tahap analisis itu diuraikan sebagai berikut

Data yang terkumpul melalui observasi ditelaah dengan proses transkripsi hasil. Data dikelompokkan berdasarkan data pada tiap siklus.

Data keseluruhan yang terkumpul diseleksi dan diidentifikasi berdasarkan kelompoknya dan mengklasifikasikan data sesuai dengan kebutuhan.

Penyajian data dengan cara mengorganisasikan informasi yang telah direduksi. Keseluruhan data dirangkum dan disajikan secara terpadu sesuai siklus yang direncanakan sehingga fokus pada pembelajaran.

Akhir temuan penelitian disimpulkan dan dilakukan kegiatan triangulasi data atau pengujian temuan penelitian. Keabsahan data diuji dengan memikirkan kembali hal-hal yang telah dilakukan dan dikemukakan melalui tukar pendapat dengan ahli dan pembimbing, teman sejawat, peninjauan kembali hasil observasi, serta triangulasi dengan teman sejawat.

Data hasil yang diperoleh dianalisis melalui tahap analisis, sebagai berikut:

1) Seleksi data

Pada tahap ini, akan diperoleh data yang memenuhi syarat untuk dianalisis sehingga kesimpulan yang diperoleh dalam penelitian ini tidak meragukan. Data yang memenuhi syarat untuk dianalisis adalah data yang beridentitas lengkap dan jelas dan dikerjakan sesuai petunjuk kerja yang telah ditetapkan.

2) Koreksi data

Data hasil tes mengidentifikasi unsur-unsur intrinsik cerita pendek dikoreksi berdasarkan criteria penilaian

3) Pembobotan data

Hasil tes mengidentifikasi unsurunsur intrinsik cerita pendek dengan lima kriteria penilaian yang dihitung berdasarkan jumlah skor.

4) Penyimpulan data
Pada tahap penyimpulan, keberhasilan penggunaan model respons analisis untuk mengidentifikasi unsur-unsur intrinsik cerita pendek ditentukan berdasarkan tabel penentuan patokan dengan perhitungan persentase yang menggambarkan kemampuan siswa.

Penerapan model respons analisis dalam upaya meningkatkan mengidentifikasi unsur-unsur intrinsik cerita pendek pada siswa kelas XI SMA Negeri 1 Cendana Kabupaten Enrekang. Dikaitkan dengan ketuntasan belajar, jika siswa yang mendapat nilai 67 ke atas $>75 \%$, maka penggunaan model respons analisis dalam pembelajaran mengidentifikasi unsur-unsur intrinsik cerita pendek dikatakan berhasil.

Tabel 3.1 Penentuan Patokan dengan Perhitungan Persentase

\begin{tabular}{|l|l|l|l|l|}
\hline \multirow{2}{*}{ No. } & $\begin{array}{l}\text { Interval } \\
\text { Persentase } \\
\text { Tingkat } \\
\text { Penguasaan }\end{array}$ & $\begin{array}{l}\text { Nilai } \\
\text { Ubah } \\
\text { Skala } \\
\text { Lima }\end{array}$ & \multirow{2}{*}{ Keterangan } \\
\cline { 3 - 4 } & & $\begin{array}{l}\text { E-4 } \\
\text { A }\end{array}$ & \\
\hline 1. & $85-100$ & 4 & A & Baik Sekali \\
\hline 2. & $75-84$ & 3 & B & Baik \\
\hline 3. & $60-74$ & 2 & C & Cukup \\
\hline 4. & $4-59$ & 1 & D & Kurang \\
\hline 5. & $0-39$ & 0 & E & Gagal \\
\hline
\end{tabular}

(Diadaptasi Nurgiyantoro, 2009:399)

Kemampuan siswa dalam mengidentifikasi unsur-unsur intrinsik cerpen didasarkan pada lima hal pokok, yaitu:

1) Menjelaskan 4 unsur-unsur intrinsik cerita pendek.

2) Menentukan tema cerita pendek.

3) Menjelaskan 4 tokoh dan penokohan cerita pendek.

4) Menentukan alur cerita pendek.

5) Menentukan latar cerita pendek.

\section{PEMBAHASAN}

Permasalahan utama penelitian ini yakni usaha untuk meningkatkan kemampuan pada proses dan hasil 
pembelajaran mengidentifikasi unsur-unsur intrinsik cerita pendek melalui model respons analisis.

\section{A. Deskripsi Hasil Penelitian Data Proses Pembelajaran Mengidentifikasi Unsur-Unsur Intrinsik Cerita Pendek melalui Respons Analisis}

a. Deskripsi Hasil Penelitian Data Proses Pembelajaran Siklus Pertama

Siklus pertama dilaksanakan berdasarkan rencana pelaksanaan yang telah dibuat oleh peneliti bersama dengan guru.

\section{1) Perencanaan}

Pada siklus pertama, persiapan yang dilakukan dalam bentuk rencana pelaksanaan pembelajaran (RPP) dan rencana kegiatan yang akan dilakukan oleh peneliti, guru, dan siswa.

Kegiatan peneliti meliputi (1) berkolaborasi dengan guru menyusun RPP dengan memilih model respons analisis sebagai model yang sesuai dalam pembelajaran mengidentifikasi unsur-unsur intrinsik cerita pendek, (2) membantu guru memilih cerita pendek yang relevan di tingkat SMA,(3) membantu guru pada saat proses belajar-mengajar berlangsung, (4) membuat lembar observasi untuk mengamati kondisi pembelajaran di kelas ketika pelaksanaan tindakan sedang berlangsung, (5) membuat alat evaluasi untuk mengukur peningkatan hasil belajar mengidentifikasi unsur-unsur intrinsik cerita pendek melalui model respons analisis setelah melakukan serangkaian tindakan siklus pertama.

Kegiatan guru, meliputi

berkolaborasi dengan peneliti membuat RPP dengan memilih model respons analisis sebagai model yang sesuai dalam pembelajaran mengidentifikasi unsur-unsur intrinsik cerita pendek, (2) berkolaborasi dengan peneliti memilih cerita pendek yang relevan di tingkat SMA, (3) melakukan aktivitas pembelajaran sesuai dengan petunjuk dalam RPP, (4) bersama peneliti melakukan tes siklus pertama, (5) bersama peneliti mengidentifikasi faktor penghambat dan pendukung proses pembelajaran, (6) memberikan umpan balik kepada siswa.

Kegiatan siswa, meliputi: mengikuti kegiatan pembelajaran, (2) menyelesaikan tes hasil belajar, (3) menerima umpan balik dari guru, (4) mengisi lembar observasi.

Pengamatan dilakukan oleh peneliti terhadap kegiatan guru dan siswa selama proses pembelajaran mengidentifikasi unsurunsur intrinsik cerita pendek berlangsung (berdasarkan lembar observasi).

2) Pelaksanaan Tindakan dan Pengamatan Pembelajaran

Pada tahap ini, guru melaksanakan pembelajaran berdasarkan RPP yang telah dibuat sedangkan peneliti mengamati proses pembelajaran mengidentifikasi unsur-unsur intrinsik cerpen melalui model respons analisis sebagai sumber data kualitatif berdasarkan lembar observasi.

Berdasarkan hasil pengamatan terhadap kegiatan pembelajaran mengidentifikasi unsur-unsur intrinsik cerita pendek melalui model respons analisis pada siklus pertama, diperoleh gambaran bahwa kegiatan pelaksanaan belum terlaksana dengan baik atau belum maksimal. Belum maksimalnya kegiatan tersebut berdampak pada hasil belajar pada siswa

Dari keseluruhan aspek yang diamati dapat disimpulkan bahwa sebesar 62,2\% siswa aktif mengikuti pembelajaran dan berdasarkan penentuan patokan dengan perhitungan persentase. Secara keseluruhan aspek yang diamati berkategori kurang.

\section{3) Refleksi Hasil Pembelajaran}

Kegiatan refleksi dilakukan secara kolaboratif antara peneliti dengan guru untuk membahas dan menyimpulkan tentang temuan dan hasil penelitian siklus pertama. Berdasarkan data proses siklus pertama diketahui bahwa dalam proses pembelajaran 
mengidentifikasi unsur-unsur intrinsik cerita pendek dengan menggunakan model respons analisis terdapat siswa yang berperilaku aktif dan tidak aktif selama proses belajar mengajar berlangsung. Siswa yang berperilaku aktif berarti siswa yang dalam proses pembelajaran bersikap positif, sedangkan siswa yang tidak aktif berarti siswa yang dalam proses pembelajaran bersikap negatif.

Hasil temuan keaktifan siswa mengikuti pembelajaran sebesar $62,2 \%$ siswa menunjukkan belum mencapai target penilaian yang ditetapkan. Target penilaian proses pembelajaran yang belum tercapai berdampak pula pada hasil pembelajaran siswa sehingga perlu dilanjutkan di siklus berikutnya yaitu siklus kedua.

\section{b. Deskripsi Hasil Data Proses Pembelajaran Siklus Kedua}

Pembelajaran siklus kedua dilaksanakan berdasarkan rencana pelaksanaan pembelajaran yang telah dibuat setelah merefleksi pembelajaran pada siklus pertama. Pada siklus kedua dilakukan perbaikan-perbaikan terhadap kendala yang dihadapi pada siklus pertama dan mempertahankan pencapaian pada siklus pertama sebagai upaya untuk meningkatkan hasil pada proses pembelajaran selanjutnya.

\section{1) Perencanaan}

Berdasakan hasil refleksi siklus pertama bahwa guru tidak menguasai kelas, kurang tegas dalam menyampaikan penjelasan materi, guru juga tidak mengaitkan materi pembelajaran dengan pengetahuan lain yang relevan dan dalam berdiskusi guru tidak memberikan durasi waktu kepada siswa sehinga alokasi waktunya tidak berjalan sesuai dengan yang direncanakan sebelumnya. Dalam memberikan tes, guru juga tidak memperhatikan waktunya sehingga melenceng pada rencana pelaksanaan pembelajaran.
Pada siklus kedua peneliti dan guru merumuskan rencana pelaksanaan pembelajaran tetap sama pada siklus pertama, hanya pelaksanaannya akan lebih dimaksimalkan pada kekurangankekurangan pada siklus pertama. Pengumpulan data tetap dilakukan berdasarkan lembar observasi aktivitas siswa dan kinerja siswa serta jurnal akhir siklus.

2) Pelaksanaan Tindakan dan Pengamatan

Pada tahap ini, guru melaksanakan pembelajaran berdasarkan rencana pelaksanaan pembelajaran yang telah dibuat pada tahap perencanaan. Berdasarkan pengamatan, diketahui kegiatan pembelajaran mengidentifikasi unsur-unsur intrinsik cerita pendek dengan model respons analisis siswa kelas XI IPA 2 SMA Negeri 1 Cendana Kabupaten Enrekang sudah terlaksana dengan baik. Terlaksananya pembelajaran pada siklus kedua ini merupakan suatu peningkatan dari segi proses dan berdampak positif bagi siswa.

Hasil observasi aktivitas siswa pada siklus kedua menunjukkan $81,7 \%$ siswa aktif mengikuti pembelajaran atau berkategori baik berdasarkan penentuan patokan dengan perhitungan persentase. Keaktifan sejalan dengan kinerja guru yang sudah maksimal. Jadi, kegiatan pembelajaran mengidentifikasi unsur-unsur intrinsik cerita pendek siswa kelas XI IPA 2 SMA Negeri 1 Cendana Kabupaten Enrekang tidak perlu lanjut ke siklus berikutnya.

\section{3) Refleksi Hasil Pembelajaran}

Pada tahap ini, kegiatan yang dilakukan oleh peneliti dan guru adalah mendiskusikan hasil observasi tindakan yang telah dilaksanakan, menganalisis hasil yang diperoleh pada siklus kedua dan menetapkan kesimpulan tentang hasil yang dicapai dalam meningkatkan kemampuan mengidentifikasi unsur-unsur intrinsik cerita 
pendek melalui model respons analisis. Data proses siklus kedua menunjukkan bahwa secara umum pembelajaran suah kondusif dan minat siswa dalam pembelajaran sudah meningkat yang berdampak pada terpahaminya pembelajaran mengidentifikasi unsur-unsur intrinsik cerita pendek dengan baik oleh siswa.

Hasil observasi siswa pada siklus kedua menunjukkan $81,7 \%$ siswa aktif mengikuti pembelajaran, hal ini menunjukkan terjadinya peningkatan proses pembelajaran yaitu sebesar $19,5 \%$ yang pada siklus pertama hanya sebesar $62,2 \%$ siswa. Keaktifan siswa sejalan dengan pelaksanaan kinerja guru yang sudah maksimal. Siswa yang masih berperilaku negatif atau pasif dikarenakan siswa tersebut memang pasif dalam pembelajaran manapun dan bersifat acuh tak acuh. Peningkatan keaktifan kemampuan siswa pada proses ini secara tidak langsung menyebabkan peningkatan pada hasil tes siswa.

\section{B. Deskripsi Data Hasil Pembelajaran Mengidentifikasi Unsur-unsur Intrinsik Cerita Pendek Melalui Model Respons Analisis}

Hasil penelitian untuk data hasil pembelajaran berupa tes kemampuan siswa pada akhir siklus berupa penilaian terhadap tulisan mengidentifikasi unsur-unsur intrinsik cerita pendek melalui model respons analisis. Hasil tes disajikan dalam bentuk data kuantitatif dengan penyajian data dalam bentuk tabel dan analisis berupa tafsiran terhadap isi tabel tersebut.

\section{a. Deskripsi Hasil Penelitian Data Hasil Pembelajaran Siklus Pertama}

Pada siklus pertama diperoleh data dari lima aspek penilaian, yaitu (a) menjelaskan empat unsur-unsur intrinsik cerita pendek, (b) menentukan tema cerita pendek, (c) menjelaskan empat tokoh dan penokohan cerita pendek, (d) menentukan alur cerita pendek, (e) menentukan latar cerita pendek.
1) Aspek Menjelaskan Unsur-unsur Intrinsik Cerita Pendek

Hasil pengukuran kemampuan siswa dalam menjelaskan unsur-unsur intrinsik cerita pendek dapat diketahui bahwa 16 $(80 \%)$ siswa mendapat nilai 20 atau berkategori sangat baik, $3(15 \%)$ siswa mendapat nilai 15 atau berkategori baik, dan hanya $1(5 \%)$ siswa yang mendapat nilai 10 atau berkategori cukup, sedangkan tidak ada seorangpun yang mendapat nilai 5 dan 0 . Jumlah nilai rata-rata keseluruhan siswa pada aspek kemampuan menentukan unsurunsur intrinsik cerita pendek adalah 18,9.

2) Aspek Menentukan Tema Cerita Pendek

Hasil pengukuran kemampuan siswa menentukan tema cerita pendek diketahui bahwa $8(40 \%)$ siswa mendapat nilai 10 atau berkategori baik, 3 (15\%) siswa mendapat nilai 7,5 atau berkategori cukup, 3 (15\%) siswa mendapat nilai 2,5 dan 5 atau berkategori kurang, dan $6(30 \%)$ siswa mendapat nilai 2 atau berkategori gagal. Jumlah nilai rata-rata keseluruhan siswa pada menentukan tema cerita pendek adalah 7.

\section{3) Aspek Menuliskan Tokoh dan Penokohan}

Hasil pengukuran kemampuan siswa dalam menuliskan tokoh dan penokohan diketahui bahwa 2 (10\%) siswa yang mendapat nilai 25 atau berkategori baik sekali, $12(60 \%)$ siswa yang mendapat nilai 20 atau berkategori baik, $6(30 \%)$ siswa yang mendapat nilai 10 atau berkategori kurang sedangkan yang mendapat nilai 0 tidak ada. Jumlah nilai rata-rata keseluruhan siswa pada aspek menuliskan tokoh dan penokohan adalah 16,9.

\section{4) Aspek Menentukan Alur}

Hasil pengukuran kemampuan siswa dalam menentukan alur diketahui bahwa 7 $(35 \%)$ siswa mendapat nilai 10 atau berkategori baik, tidak ada siswa yang mendapat nilai $7,5,10(50 \%)$ siswa yang 
mendapat nilai 5 atau berkategori kurang, sedangkan $3(15 \%)$ siswa yang mendapat nilai 2 atau berkategori gagal. Jumlah nilai rata-rata keseluruhan pada aspek menentukan alur adalah 6,3.

\section{5) Aspek Menentukan Latar}

Hasil pengukuran kemampuan siswa dalam menentukan latar diketahui bahwa 10 $(50 \%)$ siswa mendapat nilai 20 atau berkategori baik, 7 (35\%) siswa yang mendapat nilai 12,5 atau berkategori cukup, $3(15 \%)$ siswa mendapat nilai 7,5 atau berkategori kurang, sedangkan siswa yang mendapat nilai di bawah 5 tidak ada. Jumlah nilai rata-rata keseluruhan siswa pada aspek menentukan latar adalah 15.8.

Dari pengukuran kelima aspek di atas, maka dapat diketahui nilai tes yang diperoleh siswa alam siklus pertama. Berikut akan diuraikan perolehan nilai tes mengidentifikasi unsur-unsur intrinsik siswa dalam siklus pertama.

Tabel 4.1 Hasil Tes Mengidentifikasi Unsur-Unsur Intrinsik Cerita Pendek Siklus Pertama

\begin{tabular}{|c|c|l|l|l|l|}
\hline No. & $\begin{array}{c}\text { Nilai } \\
(\mathbf{x})\end{array}$ & $\begin{array}{l}\text { Frekue } \\
\text { nsi (f) }\end{array}$ & $\begin{array}{l}\text { Pers } \\
\text { entas } \\
\mathbf{e} \\
(\%)\end{array}$ & $\begin{array}{l}\mathbf{( x )} \mathbf{f} \\
\text { Keter } \\
\text { anga } \\
\mathbf{n}\end{array}$ \\
\hline 1. & 80 & 3 & 15 & 240 & Nilai \\
2. & 75 & 2 & 10 & 150 & rata- \\
3. & 70 & 2 & 10 & 140 & rata \\
4. & 68 & 3 & 15 & 204 & keselu \\
5. & 67 & 1 & 4,2 & 67 & ruhan \\
6. & 63 & 1 & 4,2 & 63 & siswa \\
7. & 62 & 2 & 10 & 124 & adala \\
8. & 60 & 1 & 4,2 & 60 & h 65,7 \\
9. & 57 & 1 & 4,2 & 57 & \\
10. & 53 & 1 & 4,2 & 53 & \\
11. & 52 & 2 & 10 & 104 & \\
12. & 51 & 1 & 4,2 & 51 & \\
\cline { 1 - 3 } Jumlah & 20 & 100 & 1313 & \\
\hline
\end{tabular}

Berdasarkan tabel 4.1 nilai yang diperoleh siswa pada siklus pertama yaitu $80,75,70,68,67,63,62,60,57,53,52$, dan
51. Nilai rata-rata yang diperoleh siswa adalah 65,7 .

Hasil tes mengidentifikasi unsurunsur intrinsik cerita pendek berdasarkan penentuan patokan dengan perhitungan persentase ditunjukkan pada tabel berikut:

\section{Tabel 4.2 Hasil Tes Mengidentifikasi} Unsur-Unsur Intrinsik Siklus Pertama Berdasarkan Penentuan Patokan dengan Perhitungan Persentase

\begin{tabular}{|c|c|c|c|c|c|}
\hline No. & $\begin{array}{c}\text { Ketera- } \\
\text { ngan }\end{array}$ & \begin{tabular}{|l|} 
Interval \\
Tingkat \\
Pengua- \\
saan \\
\end{tabular} & $\mathbf{F}$ & $\begin{array}{l}\text { Pers } \\
\text { enta } \\
\text { se } \\
\end{array}$ & $\begin{array}{l}\text { Ketera- } \\
\text { ngan }\end{array}$ \\
\hline $\begin{array}{l}1 . \\
2 . \\
3 . \\
4 . \\
5 .\end{array}$ & \begin{tabular}{|l} 
Baik \\
sekali \\
Baik \\
Cukup \\
Kurang \\
Gagal \\
\end{tabular} & $\begin{array}{c}85-100 \\
75-84 \\
60-74 \\
40-59 \\
0-30\end{array}$ & $\begin{array}{l}\mathbf{0} \\
5 \\
1 \\
0 \\
5 \\
0\end{array}$ & $\begin{array}{l}0 \\
25 \\
50 \\
25 \\
0\end{array}$ & \multirow{2}{*}{$\begin{array}{l}\text { Siswa } \\
\text { yang } \\
\text { mendapat } \\
\text { nilai } 67 \\
\text { ke atas } \\
\text { sebanyak } \\
11 \text { siswa } \\
\text { atau } \\
55 \% \text {. } \\
\text { Berdasar } \\
\text { kan } \\
\text { tingkat } \\
\text { interval } \\
\text { penguasa } \\
\text { an berada } \\
\text { pada } \\
\text { kategori } \\
\text { kurang. }\end{array}$} \\
\hline & & & $\begin{array}{l}2 \\
0\end{array}$ & 100 & \\
\hline
\end{tabular}

Berdasarkan tabel, tes mengidentifikasi unsur-unsur intrinsik cerita pendek berdasarkan penentuan patokan dengan perhitungan persentase bahwa siswa yang mendapatkan nilai 67 ke atas sebanyak 11 atau 55\% siswa dari keseluruhan siswa yang memperoleh nilai $67 \mathrm{ke}$ atas artinya msih kurang dari target penelitian, yaitu siswa yang mendapat nilai hasil belajar 67 ke atas $\geq 75 \%$, sehingga penelitian dilanjutkan ke siklus kedua dengan mempertahankan pencapaian di siklus pertama. 


\section{b. Deskripsi Hasil Penelitian Data Hasil Pembelajaran Siklus Kedua}

Pada siklus kedua diperoleh data dari lima aspek penilaian, yaitu (a) menjelaskan empat unsur-unsur intrinsik cerita pendek, (b) menentukan tema cerita pendek, (c) menjelaskan 4 tokoh dan penokohan cerita pendek, (d) menentukan alur cerita pendek, (e) menentukan latar cerita pendek.

\section{1) Aspek Menjelaskan Unsur-Unsur Intrinsik Cerita Pendek}

Hasil pengukuran kemampuan siswa dalam menjelaskan unsur-unsur intrinsik cerita diketahui bahwa 19 (90\%) siswa yang mendapat nilai 20 atau berkategori baik, 1 (5\%) siswa yang mendapat nilai 15 atau berkategori baik, 1 atau (5\%) siswa yang mendapat nilai 10 atau berkategori cukup, dan tidak ada seorang siswa pun yang berkategori gagal. Jumlah keseluruhan nilai rata-rata pada aspek menjelaskan unsurunsur intrinsik cerita pendek adalah 19.

Berdasarkan perbandingan jumlah nilai rata-rata keseluruhan siswa pada siklus pertama dan kedua dapat disimpulkan bahwa terjadi peningkatan kemampuam siswa pada aspek menjelaskan unsur-unsur intrinsik cerita pendek.

\section{2) Aspek Menentukan Tema Cerita Pendek}

Hasil pengukuran kemampuan siswa menentukan tema cerita pendek diketahui bahwa $13(60 \%)$ siswa mendapat nilai 10 atau berkategori baik, 1 (5\%) siswa mendapat nilai 7,5 atau berkategori cukup, 6 $(30 \%)$ siswa mendapat nilai 5 atau berkategori kurang, dan tidak seorangpun siswa yang berkategori gagal. Jumlah nilai rata-rata keseluruhan siswa pada menentukan tema cerita pendek adalah 8.4.

Berdasarkan perbandingan jumlah nilai rata-rata keseluruhan siswa pada siklus pertama dan siklus kedua dapat disimpulkan bahwa kemampuan siswa dalam menentukan tema cerita pendek mengalami peningkatan.
3) Aspek Menuliskan Tokoh dan Penokohan

Hasil pengukuran kemampuan siswa dalam menuliskan tokoh dan penokohan diketahui bahwa 8 (40\%) siswa yang mendapat nilai 25 atau berkategori baik sekali, $12(60 \%)$ siswa yang mendapat nilai 20 atau berkategori baik, sedangkan yang berkategori cukup, kurang dan gagal tidak ada. Jumlah nilai rata-rata keseluruhan siswa pada aspek menuliskan tokoh dan penokohan adalah 22 .

Berdasarkan perbandingan jumlah nilai rata-rata keseluruhan siswa pada siklus pertama dan kedua dapat disimpulkan bahwa terjadi peningkatan kemampuan siswa pada aspek menuliskan tokoh dan penokohan.

\section{4) Aspek Menentukan Alur}

Hasil pengukuran kemampuan siswa dalam menentukan alur diketahui bahwa 17 $(8 \%)$ siswa mendapat nilai 10 atau berkategori baik, tidak ada siswa yang mendapat nilai 7,5 atau berkategori kurang, $3(15 \%)$ siswa yang mendapat nilai 5 atau berkategori kurang, dan tidak ada siswa yang berkategori gagal. Jumlah nilai ratarata keseluruhan pada aspek menentukan alur adalah 9,2.

Berdasarkan perbandingan jumlah nilai rata-rata keseluruhan siswa pada siklus pertama dan kedua dapat disimpulkan bahwa terjadi peningkatan kemampuan siswa pada aspek menentukan alur.

\section{5) Aspek Menentukan Latar}

Hasil pengukuran kemampuan siswa dalam menentukan latar diketahui bahwa $19(50 \%)$ siswa mendapat nilai 20 atau berkategori baik, 1 (5\%) siswa yang mendapat nilai 12,5 atau berkategori cukup, sedangkan untuk kategori kurang dan gagal tidak ada seorangpun siswa yang mendapatnya. Jumlah nilai rata-rata keseluruhan siswa pada aspek menentukan latar adalah 19,7. 
Berdasarkan perbandingan jumlah nilai rata-rata keseluruhan siswa pada siklus pertama dan kedua dapat disimpulkan bahwa terjadi peningkatan kemampuan siswa pada aspek menentukan latar.

Dari pengukuran kelima aspek di atas, maka dapat diketahui nilai tes yang diperoleh siswa dalam siklus kedua. Berikut akan diuraikan perolehan nilai tes mengidentifikasi unsur-unsur intrinsik siswa dalam siklus kedua.

Tabel 4.3 Hasil Tes Mengidentifikasi Unsur-Unsur Intrinsik Cerita Pendek Siklus Kedua

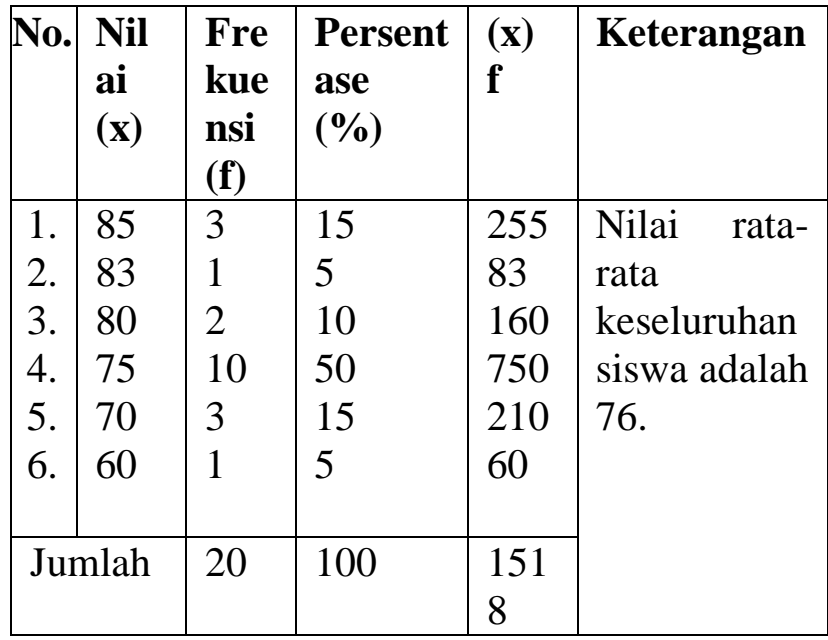

Berdasarkan tabel 4.3 nilai yang diperoleh siswa pada siklus kedua yaitu 85 , $83,80,75,70$, dan 60 . Nilai rata-rata yang diperoleh siswa adalah 76 .

Hasil tes mengidentifikasi unsurunsur tabel berdasarkan penentuan patokan dengan perhitungan persentase ditunjukkan pada tabel berikut:

Tabel 4.4 Hasil Tes Mengidentifikasi Unsur-Unsur Intrinsik Siklus Kedua Berdasarkan Penentuan Patokan dengan Perhitungan Persentase

\begin{tabular}{|l|l|l|l|l|l|}
\hline No. & $\begin{array}{l}\text { Keter } \\
\text { angan }\end{array}$ & $\begin{array}{l}\text { Interval } \\
\text { Tingkat } \\
\text { Pengua } \\
\text { saan }\end{array}$ & $\mathbf{F}$ & $\begin{array}{l}\text { Per } \\
\text { sent } \\
\text { ase }\end{array}$ & $\begin{array}{l}\text { Keteran } \\
\text { gan }\end{array}$ \\
\hline
\end{tabular}

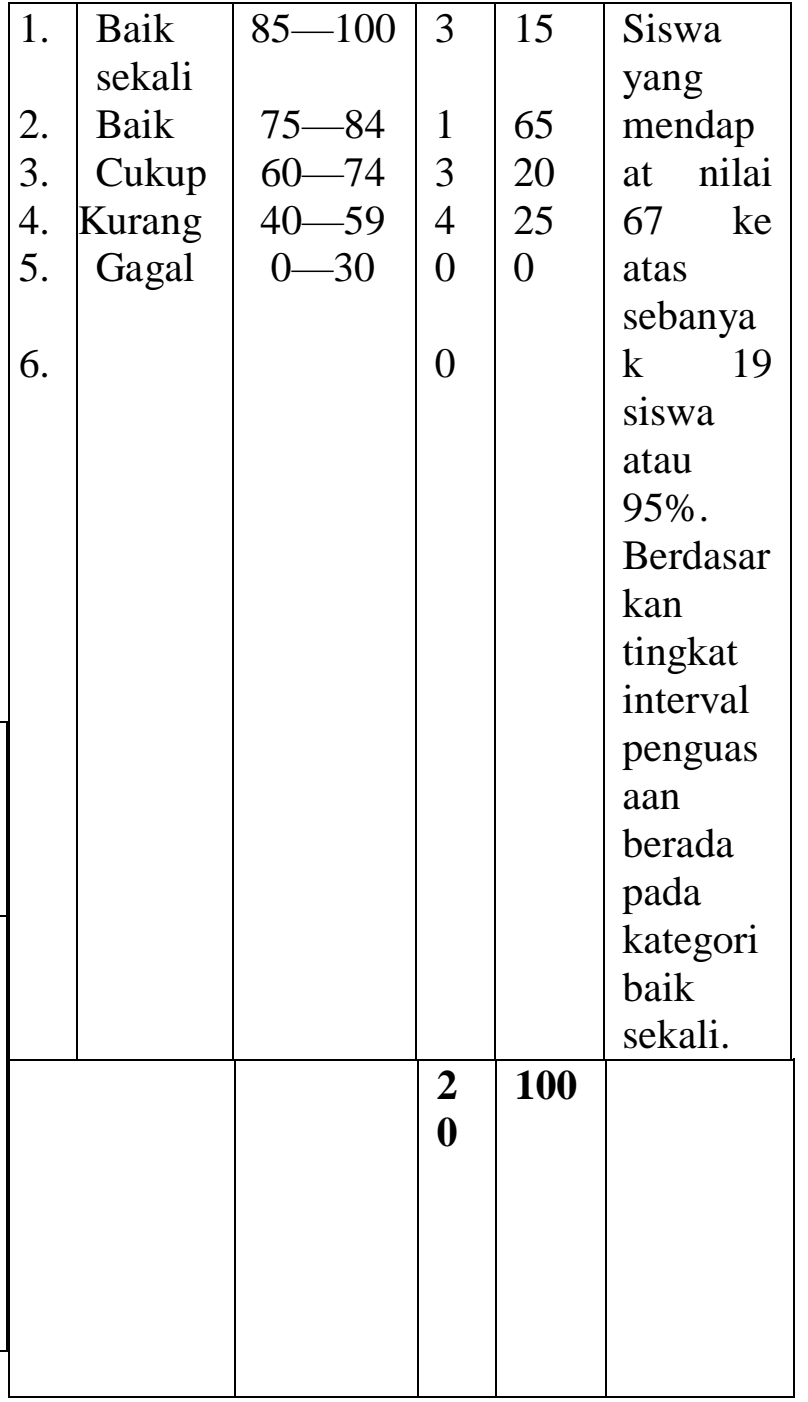

Berdasarkan tabel 4.4 hasil tes mengidentifikasi unsur-unsur intrinsik cerita pendek berdasarkan penentuan patokan dengan perhitungan persentase bahwa siswa yang mendapatkan nilai 67 ke atas sebanyak 19 atau 95\% siswa dari keseluruhan siswa yang memperoleh nilai 67 ke atas artinya tingkat penguasaan berada pada kategori baik sekali, hanya 1 siswa yang memperoleh nilai di bawah 67. Siswa yang menapat nilai di bawah 67 memang menunjukkan sikap negatif terhadap pembelajaran. Target penelitian $\geq 75 \%$ sudah terpenuhi pada siklus kedua sehingga penelitian tidak perlu lanjut ke siklus berikutnya.

\section{A. Pembahasan Siklus Pertama}

Pada siklus pertama, tampak siswa dengan perilaku positif dan negatif. Siswa 
yang berperilaku positif menunjukkan sikap aktif menjawab pertanyaan guru dan memperhatikan penyampaian guru dengan saksama, dan pada saat penyampaian materi siswa menanyakan hal yang belum terpahami. Siswa serius berdiskusi dengan saling bertukar pendapat, ketika mengerjakan tes siswa tampak serius walaupun masih ada siswa yang bertanya pada guru. Perilaku positif ini dikarenakan penggunaan model respons analisis pada pembelajaran mengidentifikasi unsur-unsur intrinsik cerita pendek, selain itu guru mata pelajaran menguasai materi pembelajaran dengan baik.

Pada pelaksanaan proses pembelajaran siklus pertama, secara umum siswa masih kurang aktif mengikuti proses pembelajaran, hanya $62,2 \%$ siswa yang aktif. Hal ini berarti, masih kurang dari target $75 \%$. Kekurangaktifan siswa pada proses pembelajaran siklus pertama berdampak pada hasil tes mengidentifikasi unsur-unsur intrinsik cerita pendek yang dicapai hanya 55\% dari target $75 \%$.

\section{Pembahasan Siklus II}

Hasil observasi aktivitas siswa pada siklus kedua menunjukkan $81,7 \%$ siswa aktif mengikuti pembelajaran, hal ini menunjukkan terjadinya peningkatan proses pembelajaran yang signifikan yaitu sebesar $19,5 \%$ yang pada siklus pertama hanya $62,2 \%$, keaktifan siswa sejalan dengan pelaksanaan kinerja guru yang sudah maksimal.

Hasil penilaian berdasarkan interval nilai yang ditetapkan menunjukkan bahwa pada siklus kedua 95\% dari target $75 \%$ siswa memperoleh nilai 67 , ini berarti terjadi peningkatan hasil belajar sebagai dampak dari peningkatan proses pembelajaran, sehingga pembelajaran mengidentifikasi unsur-unsur intrinsik cerita pendek melalui model respons analisis di kelas XI IPA 2 SMA Negeri 1 Cendana Kabupaten Enrekang dinyatakan berhasil.

\section{PENUTUP}

Berdasarkan hasil analisis data dan pembahasan, penelitian dapat disimpulkan sebagai berikut:

1) Penggunaan model respons analisis dapat meningkatkan proses mengidentifikasi unsur-unsur intrinsik cerita pendek siswa kelas XI IPA 2 SMA Negeri 1 Cendana Kabupaten Enrekang. Pada siklus pertama, siswa siswa yang mengikuti pembelajaran sebesar $62,2 \%$, sedangkan pada siklus kedua sebesar $81,1 \%$.

2) Penggunaan model respons analisis dapat meningkatkan hasil mengidentifikasi unsur-unsur intrinsik cerita pendek siswa kelas XI SMA Negeri 1 Cendana Kabupaten Enrekang. Pada siklus pertama, siswa yang memperoleh nilai 67 ke atas sebesar 55\% dengan nilai rata-rata sebesar 65,7, sedangkan pada siklus kedua, siswa yang memperoleh nilai 67 ke atas sebesar $95 \%$ dengan nilai rata-rata sebesar 76 .

Berdasarkan hasil penelitian ini, maka peneliti menyarankan:

1) Guru diharapkan dapat memberikan variasi-variasi dalam pembelajaran sastra, khususnya penggunaan model pembelajaran mengidentifikasi unsurunsur intrinsik cerita pendek.

2) Bagi peneliti lain dan mahasiswa yang menekuni bidang bahasa dan sastra Indonesia diharapkan melakukan penelitian di bidang sastra dengan menggunakan model yang lain.

3) Para praktisi atau peneliti di bidang pendidikan dan bahasa dapat menggunakan penelitian ini sebagai bahan rujukan untuk melakukan penelitian yang lain dengan model pembelajaran yang berbeda sehingga didapatkan berbagai alternatif model pembelajaran.

\section{DAFTAR PUSTAKA}

Aminuddin. 2009. Pengantar Apresiasi Sastra. Bandung: Sinar Baru Algensindo. 
Arikunto, Suharsimi. 2006. Prosedur Penelitian suatu Pendekatan Praktik. Mataram: Rineka Cipta.

Arikunto, Suharsimi, dkk. 2009. Penelitian Tindakan Kelas. Jakarta: Bumi Aksara.

Djumingin, dkk. 2009. Perencanaan Pembelajaran Bahasa dan Sastra Indonesia Berbasis Kurikulum Tingkat Satuan Pendidikan (KTSP): Teori dan Penerapannya. Makassar: Badan Penerbit UNM.

Dola, Abdulla. 2007. "Bahan Ajar Apresiasi Prosa Fiksi dan Drama". Makassar: Badan Penerbit UNM

Gani, Rizanur. 1988. Pengajaran Sastra Indonesia Respons dan Analisis. Padang: Dian Dinamika Press.

Hajrah, dkk. 2009. "Penerapan Model Respons Analisis dan Model Moody dalam Pembelajaran Apresiasi Cerita Pendek". Penelitian (Tidak Diterbitkan). FBS UNM

Muslich, Masnur. 2009. Melaksanakan Penelitian Tindakan Kelas itu Mudah. Jakarta: Bumi Aksara.

Nurgiyantoro, Burhan. 2007. Teori Pengkajian Fiksi. Yogyakarta: Gadjah Mada University Press.
Nurgiyantoro, Burhan. 2009. Penilaian dalam Pengajaran Bahasa dan Sastra Edisi Ketiga. Yogyakarta: BPFE.

Stanton, Robert. 2007. Teori Fiksi Robert Stanton. Yogyakarta: Pustaka Pelajar Offset.

Syaifullah. Abstrak Thesis archive at Program Studi Bahasa Indonesia. Penerapan Model Respons Analisis dan Model Moody dalam Pembelajaran dan Pendekatan Keterampilan Proses dalam Pembelajaran Apresiasi Cerpen ...ind. sps.upi.edu/?cat $=3$ \&paged $=3$

Tanggal 23 April 2010. Publikasi tgl 8 maret 2010 01.55. 2008

Tarigan, Henry Guntur. 2008. Menyimak Sebagai Suatu Keterampilan Berbahaasa. Bandung: Penerbit Angkasa Bandung.

Teeuw. A. 1988. Sastra dan Ilmu Sastra Pengantar Teori Sastra. Jakarta: PT Girimukti Pasaka.

Umar, Alimin, dkk. 2008. "Penelitian Tindakan Kelas (Pengantar ke Dalam Pemahaman Konsep dan Aplikasi)". Makassar: Badan Penerbit UNM. 